\title{
Postoperative Fibrin Reaction and Descemet Membrane Detachment: A Case Report
}

\author{
Postoperatif Fibrin Reaksiyon ve Descemet Membranı Dekolmanı: Olgu Sunumu
}

\author{
(D) Mustafa Suat Alıkma, (D) Erkan Ünsal, (D) Tülay Akçetin, (D) Mehmet Özgür Çubuk, (D) Kadir Eltutar \\ İstanbul Training and Research Hospital, Clinic of Ophthalmology, İstanbul, Turkey
}

\begin{abstract}
An 85-year-old male patient who underwent phacoemulsification and intraocular lens implantation surgery in the right eye one week ago was admitted to our clinic for first week control. The patient stated that his vision had decreased slowly from post-operative day 1. Anterior segment examination revealed corneal edema, wrinkle in Descemet membrane, anterior chamber fibrin reaction and pseudophakic in the right eye. The left eye was phakic. Visual acuity (VA) was counting fingers at 3 meters in the right and 0.1 in the left eye. Intraocular pressure (IOP) was $14 \mathrm{mmHg}$ in both right and left eyes. In the fundus examination, the right retina could not be evaluated clearly. In ultrasonography examination, the right retina was attached. Fundus examination of the left eye was normal. In the patient's recorded notes on postoperative day 1 , VA of the right eye was 0.4 and IOP was $14 \mathrm{mmHg}$, and the anterior segment examination revealed clear cornea and quiet anterior chamber. In the postoperative first week, $25 \mu \mathrm{g} / \mathrm{mL} 0.1 \mathrm{cc}$ tissue plasminogen activator injection was performed due to fibrin reaction in the anterior chamber. As wrinkle in Descemet membrane and corneal edema persisted despite the regression of fibrin one day after injection, anterior segment optical coherence tomography (OCT) was performed for suspected Descemet membrane detachment. Total Descemet membrane detachment was observed in OCT. Sulfur hexafluoride (SF6) was injected into the anterior chamber to treat Descemet membrane detachment. It was observed that corneal edema and keratic stria disappeared, VA increased to 0.3 , IOP was 14 $\mathrm{mmHg}$, cornea was clear, there was gas in the anterior chamber and the fibrin was completely regressed on the first day after SF6 injection. In this study, we aimed to present a case with total Descemet membrane detachment with accompanying postoperative fibrin membrane and our successful treatment.
\end{abstract}

Keywords: Descemet membrane detachment, fibrin reaction, phacoemulsification, tPA

\section{öz}

Bir hafta önce sağ gözünden fakoemülsifikasyon ve göz içi lens cerrahisi olan 85 yașındaki erkek hasta, tarafımıza 1. hafta kontrolü için başvurdu. Hasta ameliyatın 1. gününden itibaren görmesinin yavaşça azaldığını ifade etti. Ön segment muayenesinde sağ gözde kornea ödemi, Descemet membranında kırışıklık, ön kamarada fibrin reaksiyon ve psödofakik izlendi. Sol göz fakik idi. Görme keskinliği (GK) sağda 3 metreden parmak sayma (mps), solda 0,1 seviyesinde, göz içi basıncı (GiB) sağ ve solda $14 \mathrm{mmHg}$ olarak izlendi. Fundus muayenesinde sağ retina net olarak değerlendirilemedi. Ultrasonografi'de sağ retina yatıșık izlendi. Sol göz fundus muayenesi doğal gözlendi. Hastanın postoperatif 1. gün kontrolünde kaydedilmiş notlarında sağ göz GK seviyesi 0,4, GiB $14 \mathrm{mmHg}$ idi, ön segment muayesinde korneanın saydam ve ön kamaranın sakin olduğu izlendi. Postoperatif 1. haftada ön kamarada fibrin reaksiyon olması nedeniyle $25 \mu \mathrm{g} / \mathrm{mL} \mathrm{0,1} \mathrm{cc} \mathrm{doku} \mathrm{plazminojen} \mathrm{aktivatörü} \mathrm{enjeksiyonu}$ uygulandı. Enjeksiyondan 1 gün sonra fibrinin gerilemesine rağmen Descemet membran kırışıklığının ve kornea ödeminin aynı şekilde devam etmesi nedeniyle Descemet membran dekolmanı şüphesiyle ön segment optik koherans tomografi (OCT) çekildi. Çekilen OCT'de total Descemet membran dekolmanı izlendi. Descemet membran dekolmanını tedavi etmek amaçlı ön kamaraya sülfür hekzaflorür (SF6) enjeksiyonu uygulandı. SF6 enjeksiyonu sonrası ilk gün kornea ödeminin ve keratik strianın kaybolduğu, GK'nin 0,3 seviyesine çıktığı, GiB'nin 14 mmHg, korneanın saydam olduğu, ön kamarada gaz olduğu ve fibrinin tamamen gerilemiş olduğu gözlendi. Bu çalışmamızda postoperatif fibrin membrana eşlik eden total Descemet membran dekolmanı olan bir olguyu ve başarılı olan tedavimizi sunmayı amaçladık.

Anahtar Kelimeler: Descemet membran dekolmanı, fibrin reaksiyon, fakoemülsifikasyon, tPA
Address for Correspondence/Yazıșma Adresi: Mustafa Suat Alıkma, İstanbul Training and Research Hospital, Clinic of Ophthalmology, İstanbul, Turkey

Phone: +90 5321715571 E-mail: m.suatalikma@gmail.com ORCID ID: orcid.org/0000-0002-3621-1892

Cite this article as/Atıf: Alıkma MS, Ünsal E, Akçetin T, Çubuk MÖ, Eltutar. Postoperative Fibrin Reaction and Descemet Membrane Detachment: A Case Report. İstanbul Med J 2019; 20(2): 165-8.
Received/Geliș Tarihi: 20.05.2017 Accepted/Kabul Tarihi: 28.05.2018

(c) Copyright 2019 by the Istanbul Training and Research Hospital/Istanbul Medical Journal published by Galenos Publishing House.

(C) Telif Hakkı 2019 Istanbul Ĕgitim ve Araștırma Hastanesi/Istanbul Tıp Dergisi, Galenos Yayınevi tarafından basılmıștır. 


\section{Introduction}

Cataract surgery has become a less aggressive surgery in the light of recent surgical techniques and accompanying technological advances. Over the years, the incisions got smaller in the surgical techniques, thus resulting in less postoperative inflammation and astigmatism (1). At the same time, intraocular pressure (IOP) has become more stable during surgery as an advantage of surgery in a closed environment, and as a result, complications such as choroidal bleeding have become less common (2).

Despite all these advances in surgical technique, Descemet membrane detachment may occur due to surgical instruments entering the eye from the corneal incision. Progressive post-operative corneal edema is an alerting factor for the surgeon (3). The definitive diagnosis is made by anterior segment optical coherence tomography (OCT) (4). Sterile air, sulfur hexafluoride (SF6) gas and perfluoropropane (C3F8) gas can be injected into the anterior chamber for the treatment of Descemet membrane detachment (5-7).

Post-operative inflammation can be controlled by the use of antiinflammatory drugs that suppress inflammation in the eye. Antibiotic treatment in addition to anti-inflammatory treatment is important for endophthalmitis prophylaxis (8). In addition to surgical trauma, BSS solution used to generate volume during surgery, molecular structures and production techniques of viscoelastic substances are also effective in the development of post-operative inflammation (9).

In this study, we aimed to present a case with Descemet membrane detachment and accompanying fibrin reaction after cataract surgery.

\section{Case Report}

An 85-year-old male patient who underwent phacoemulsification surgery in his right eye with a diagnosis of nuclear cataract was discharged on the first day after surgery with clear cornea, (+1) cell in the anterior chamber and normal IOP. Moxifloxacin eye drop seven times a day (Avelox, Alcon) and prednisolone eye drop seven times a day (Pred Forte, Allergan) were prescribed after discharge. The patient was called for control examination after 1 week. In the post-operative first week control, it was observed that the cornea was edematous, there were keratic striae, the anterior chamber details could not be selected clearly and there was fibrin reaction in the anterior chamber (Figure 1). Visual acuity (VA) was counting fingers at 3 meters and IOP was 14 $\mathrm{mmHg}$. Posterior segment examination with indirect ophthalmoscope could not be performed due to corneal edema and fibrin membrane. In the fundus examination, only normal retinal reflection could be observed. In ultrasonography examination, the retina was attached and the vitreous was normal. The patient stated that he had seen well on the morning after the surgery, but that VA decreased slowly within one week. The absence of these findings on the morning of post-operative day one and the detection of these findings after 1 week confirmed the statements of the patient. The patient had no complaints of pain, but he had complaints of stinging and burning. Endophthalmitis was considered initially, however, this diagnosis could not be made due to lack of pain and presence of normal vitreous. Because of fibrin reaction, $25 \mu \mathrm{g} / \mathrm{mL} 0.1$ cc alteplase [tissue plasminogen activator (tPA), Actilyse,
Boehringer Ingelheim Pharmaceuticals Inc., Germany)] was injected into the anterior chamber initially. On the first day after injection, fibrin reaction and flare were observed to regress. However, it was thought that there might be Descemet membrane detachment due to persistence of keratic striae and corneal edema $(6,10)$. An anterior segment OCT (3D-2000 Series, Topcon, Japan) was performed to support this diagnosis. Descemet membrane detachment was detected in OCT (Figure 2). The cause of progressive corneal edema and keratic striae was thought to be Descemet membrane detachment. 0.05 cc of pure

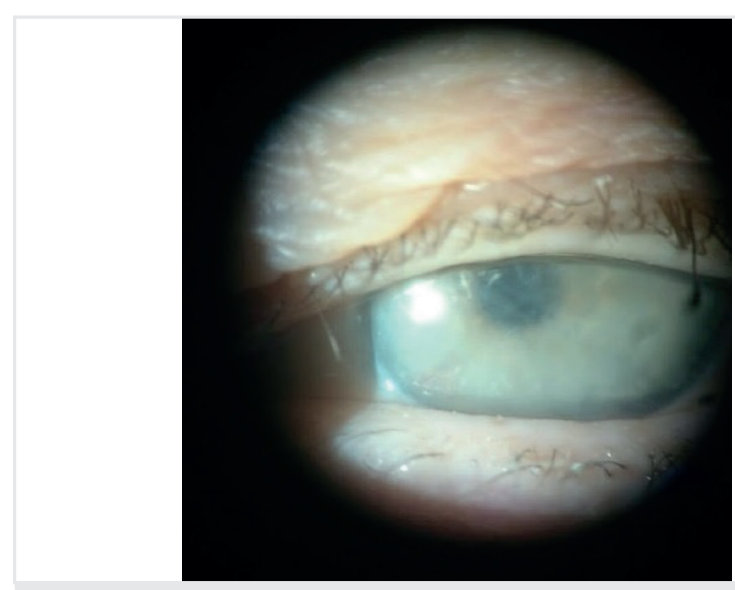

Figure 1. Corneal edema, keratic striae and fibrin reaction in the anterior chamber

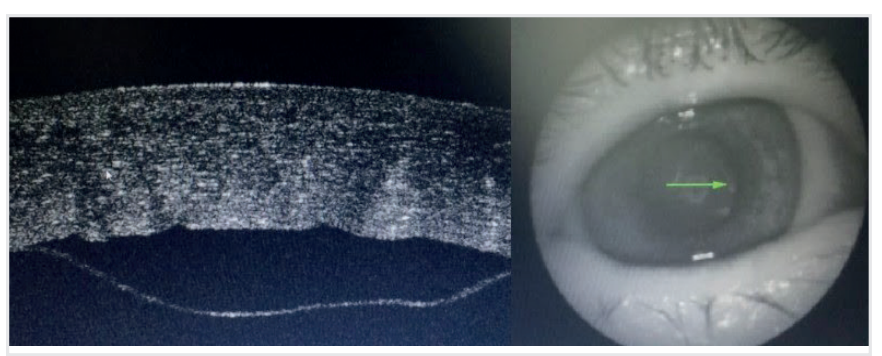

Figure 2. Descemet membrane detachment in the anterior chamber in optical coherence tomography

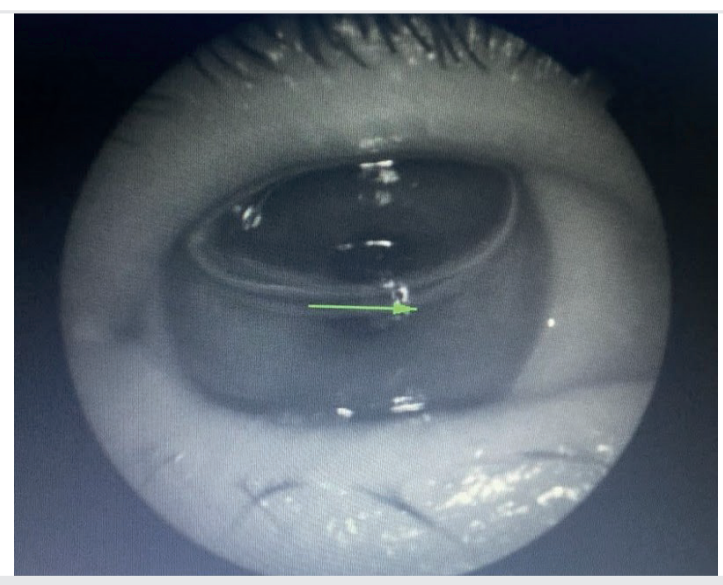

Figure 3. Gas seen after injection of sulfur hexafluoride 6 into the anterior chamber 


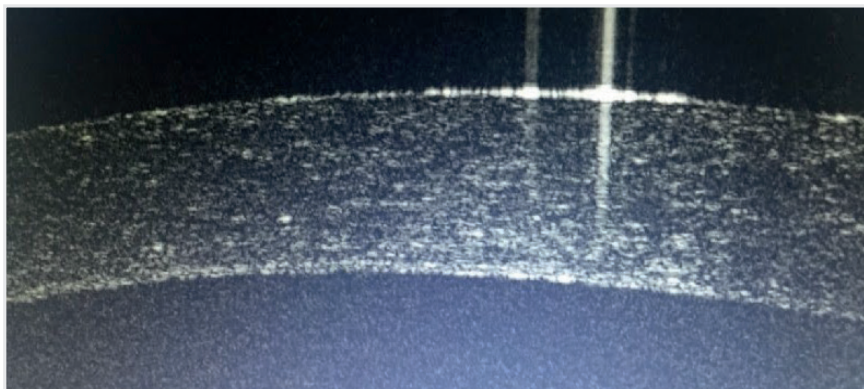

Figure 4. Regressed Descemet membrane detachment after the injection of sulfur hexafluoride 6 into anterior chamber and its visualization in optical coherence tomography

SF6 gas (Vefa Medical, Turkey) was injected into the anterior chamber. On the evening of the injection, the patient was ensured to lie on his back and to look at the ceiling. On the next day, although there was air-fluid limit just above the optical axis, it was found that the VA was 0.3 , corneal edema regressed and keratic striae decreased (Figure 3 ). The weekly examinations showed that the gas in the anterior chamber was slowly absorbed, the fibrin reaction in the anterior chamber did not develop again, and the cornea remained normal. The control OCT also confirmed that Descemet membrane was attached (Figure 4). Written informed consent was obtained from the patient for this study.

\section{Discussion}

In case of dominant post-operative inflammation for various reasons, fibrin reaction may be observed in the anterior chamber depending on the number of cells and severity of inflammation (11). Therefore, the possibility of post-operative fibrin reaction is higher in patients with uveitis (12). Reaction time in the anterior chamber advice the surgeon whether the reaction is sterile or infective. In case of intense cell and fibrin reaction in the anterior chamber on post-operative day one, toxic anterior segment syndrome (TASS) is considered initially (13). TASS is not infective and responds well to topical and systemic steroids $(14,15)$. In the reaction occurring later in the post-operative period, infective causes are more likely. Infective reasons should be considered in the anterior chamber reactions, especially after the post-operative day four (16). TASS has painless anterior chamber reaction and hypopion, whereas eye pain and perilimbal injection are accompanied to this situation in infective anterior chamber reactions (14). In our patient, we suspected infective anterior chamber reaction due to the formation of anterior chamber reaction in the late period and presence of accompanying $(++++)$ cells in the anterior chamber. However, we thought that the patient could have an inflammatory event due to the lack of hyperemia in his conjunctiva, land ack of ciliary injection and pain. Since we considered an inflammatory event in the patient, we injected tPA into the anterior chamber, which can be used to treat the fibrin reaction (17). Although the dose of injected tPA was different in many studies, we used the same treatment dose in another study conducted in our country (18). While the fibrin reaction and flare were regressed with treatment, we suspected endothelial insufficiency due to Descemet wrinkles and corneal edema, and performed anterior segment OCT. We detected Descemet membrane detachment in the OCT. We injected 0.05 cc of SF6 gas into the anterior chamber to treat Descemet membrane detachment. As a result, observation of fibrin reaction and cell in the anterior chamber in the post-operative period may be predictive of two different clinical entities according to time. TASS was observed one week after surgery in our patient, even though it is an expected finding in the post-operative day one. Ciliary injection, pain, and hyperemia in anterior chamber reactions also guide the ophthalmologist about the severity of the situation.

\section{Conclusion}

In patients with a prediagnosis of TASS, the observation of keratic striae, as well as corneal edema, may give the physician an idea about accompanying Descemet membrane detachment. In this situation, it is possible to treat Descemet membrane detachment with sterile air, SF6 gas and C3F8 gas injected into the anterior chamber.

Informed Consent: Written informed consent was obtained from the patient for this study.

Peer-review: Externally peer-reviewed.

Author Contributions: Concept - M.S.A., E.Ü., T.A., M.Ö.Ç., K.E.; Design - M.S.A., E.Ü., T.A., M.Ö.Ç., K.E.; Supervision - M.S.A., E.Ü., T.A., M.Ö.Ç., K.E.; Resources - M.S.A., E.Ü., T.A., M.Ö.Ç., K.E.; Materials - M.S.A., E.Ü., T.A., M.Ö.Ç., K.E.; Data Collection and/or Processing - M.S.A., E.Ü., T.A., M.Ö.C.., K.E.; Analysis and/or Interpretation - M.S.A., E.Ü., T.A., M.Ö.C.,, K.E.; Literature Search - M.S.A., E.Ü., T.A., M.Ö.Ç., K.E.; Writing Manuscript - M.S.A., E.Ü., T.A., M.Ö.Ç., K.E.; Critical Review - M.S.A., E.Ü., T.A., M.Ö.C.., K.E.

Conflict of Interest: No conflict of interest was declared by the authors.

Financial Disclosure: The authors declared that this study received no financial support.

\section{References}

1. Gözüm N. Katarakt ve tedavisi. Klinik gelișim 2012; 25: 12-5.

2. Can I, Takmaz T, Nacaroğlu ŞA, Genç I, Soyugelen G. Bimanuel küçük kesili katarakt cerrahisi. Glo-Kat 2007; 2: 227-35.

3. Bhattacharjee H, Bhattacharjee K, Medhi J, Altaf A. Descemet's membrane detachment caused by inadvertent vancomycin injection. Indian J Ophthalmol 2008; 56: 241-3.

4. Kothari S, Kothari K, Parikh RS. Role of anterior segment optical coherence tomogram in Descemet's membrane detachment. Indian J Ophthalmol 2011; 59: 303-5.

5. Ellis DR, Cohen KL. Sulfur hexafluoride gas in the repair of Descemet's membrane detachment. Cornea 1995; 14: 436-7.

6. Macsai MS, Gainer KM, Chisholm L. Repair of Descemet's membrane detachment with perfluoropropane (C3F8). Cornea 1998; 17: 129-34.

7. Kim IS, Shin JC, Im CY, Kim EK. Three Cases of Descemet's membrane detachment after Cataract Surgery. Yonsei Med J 2005; 46: 719-23.

8. Aslan L. Prevention and treatment of bacterial endophthalmitis after cataract surgery. Clin Anal Med 214; 5: 353-7.

9. Althomali TA. Viscoelastic substance in prefilled syringe as an etiology of Toxic Anterior Segment Syndrome. Cutan Ocul Toxicol 2016; 35: 237-41. 
10. Kim IS, Shin JC, Im CY, Kim EK. Three cases of descemet's membrane detachment after cataract surgery. Yonsei Med J 2005; 46: 719-23.

11. Cunha LP, Costa-Cunha LVF, Costa CF, Bastos RR, Prata TdS, Monteiro MLR. Predictive factors for anterior chamber fibrin formation after vitreoretinal surgery. Rev Bras Oftalmol 2014; 73: 93-7.

12. da Rocha Lima B, Pichi F, Nucci P, Srivastava SK, Lowder CY. Fibrin reaction after uveitic cataract surgery: treatment and prevention. Eur J Ophthalmol 2014; 24: 626-8.

13. Öner Ö, Akova YA, Usta YB. Toxic Anterior Segment Syndrome (TASS). Turk J Ophthalmol 2011; 41: 407-13.

14. Dereli G, Takmaz T. Fakoemulsifikasyon sonrası toksik anterior segment sendromu. Turk J Ophthalmol 2013; 43: 377-80.
15. Cornut PL, Chiquet C. (Toxic anterior segment syndrome). J Fr Ophtalmol 2011; 34: 58-62

16. Somani S, Grinbaum A, Slomovic AR. Postoperative endophthalmitis: incidence, predisposing surgery, clinical course and outcome. Can J Ophthalmol 1997; 32: 303-10.

17. Akçetin T, Eltutar K, Dinçer N, Özdemir F. Komplikasyonsuz katarakt ameliyatından sonra gelișen fibrin membran pupiller blok glokomunun intrakamaral tpa ile tedavisi: olgu sunumu. İstanbul Med J 2015; 16: 42-4.

18. Başarır B, Eren H, Pınarcı EY, Altan Ç, MertS, Demirok A, et al. Katarakt ameliyatı sonrası fibrin membran tedavisinde doku plazminojen aktivatörünün klinik kullanımı. Glo-Kat 2012; 7: 109-12. 